\title{
Modern systems for monitoring the stress- strain state of hazardous power generating facilities
}

\author{
Anatoly Zemlyansky ${ }^{1 *}$, Alexander Zhukov $^{2}$, and Daria Bulavina ${ }^{2}$ \\ ${ }^{1}$ Balakovo Institute of Engineering and Technology, the branch of the National Research Nuclear \\ University MEPhI (Moscow Engineering Physics Institute), Chapajeva street,140, Balakovo, \\ Saratovskaja oblast', Russia \\ ${ }^{2}$ Penza State University of Architecture and Construction, st. German Titov, 28, Penza, Russia
}

\begin{abstract}
The paper considers the issue of effectively increasing the level of operational reliability of power generating nuclear and hydraulic facilities. Over the past 20 years, the number of accidents at these facilities has been growing. There are many factors affecting the collapse of structures, but, according to the authors, the lack of a monitoring system capable of fully assessing not only the stress-strain state, but also the socalled "residual" stresses of the material is the dominant direction of research. The same question is raised at the state level, as evidenced by the requirements of the STO, GOST and Federal laws, to which the authors refer below. The legislative prerequisites (requirements) for the creation of an improved system for monitoring critical structures, corresponding to the development trends of the construction industry, as well as the modernization of the existing fund are listed. The drawbacks and advantages of existing monitoring systems (strain gauge, string, fiber-optic sensors and acoustic emission systems) are analyzed in detail, and the general lack of the possibility of measuring, evaluating "residual" stresses in the material of structures is noted. A fundamentally new system for monitoring the stress-strain state of building structures and power equipment is proposed, which is based on the Foerster effect, a comparison is made with the existing systems described above. The main features and capabilities of the method are noted and options for use at highly important facilities are proposed.
\end{abstract}

\section{Introduction}

Emergency situations at power generating facilities, despite their strategic importance and existing monitoring systems, are not rare. Table 1 highlights the main reasons for the last 20 years, the defining characteristic of which is the disruption of the normal operation of load-

*Corresponding author: zeml_aa@mail.ru 
bearing structures as a result of design errors, natural disasters, man-made disasters, etc. character

Table 1. Collapse of structures at power generating facilities.

\begin{tabular}{|c|c|}
\hline Object name & Cause of destruction \\
\hline 1 & 2 \\
\hline $\begin{array}{l}\text { Sayano } \\
\text { Shushenskaya HPP }\end{array}$ & $\begin{array}{l}\text { On August 17, 2009, due to the design features of hydraulic unit } \\
\text { No. 2, fatigue cracks formed in its fastening (pins), which, with } \\
\text { increased vibration of the entire turbine unit, led to their } \\
\text { uncontrolled destruction. As a result, the upper cover of the } \\
\text { turbine was torn off by the pressure of water [1]. }\end{array}$ \\
\hline Surgut GRES-2 & $\begin{array}{l}\text { On January } 4,2008 \text {, the roof over the boiler and turbine shop } \\
\text { collapsed. According to the conclusion of the commission, the } \\
\text { insufficient number of welded joints in individual elements of the } \\
\text { roof structure and the partial absence of the envisaged designs of } \\
\text { connecting elements between the panels, led to a significant } \\
\text { decrease in their bearing capacity. Together with the formation of } \\
\text { an unacceptable snow cover on a part of the roof surface, these } \\
\text { design flaws caused the collapse [2]. }\end{array}$ \\
\hline Berezovskaya GRES & $\begin{array}{l}\text { February 1, 2016. "The emergence of an emergency was the } \\
\text { depressurization of the fuel oil supply pipeline due to the } \\
\text { destruction of the welded joint of the branch pipe under load due } \\
\text { to resonant vibrations caused by the unsuccessful design of the } \\
\text { fuel oil pipeline," the press release says. [3]. }\end{array}$ \\
\hline $\begin{array}{l}\text { Chernobyl nuclear } \\
\text { power plant }\end{array}$ & $\begin{array}{l}\text { On February } 12,2013,600 \mathrm{~m} 2 \text { of wall panels and roofs collapsed } \\
\text { over the turbine hall of Unit } 4 \text {. According to the commission, "the } \\
\text { fall of the truss on axis } 50 \text { from row A to row B due to negative } \\
\text { factors" caused the destruction. Poor reconstruction after the } \\
\text { tragedy of } 1986 \text { caused displacement and deformation of load- } \\
\text { bearing structures, violation of the strength of welded joints, as } \\
\text { well as corrosion due to roof leaks. No visual control due to life- } \\
\text { threatening radiation levels [4]. }\end{array}$ \\
\hline $\begin{array}{l}\text { Leningradskaya NPP - } \\
2\end{array}$ & $\begin{array}{l}\text { On July } 24,2011 \text {, a technological reinforcement cage collapsed } \\
\text { during lifting to the design position [5]. }\end{array}$ \\
\hline Kursk NPP-2 & $\begin{array}{l}\text { On June } 6,2016 \text {, the metal trusses of the armored metal block } \\
\text { workshop collapsed. } \\
\text { "Lack of reliable design solutions for a rigid vertical connection } \\
\text { unit between trusses, ensuring stability, violation of the } \\
\text { technological sequence of installation work" - listed the head of } \\
\text { the state inspection of construction supervision of the Kursk } \\
\text { region, Tatiana Berezinikova [6]. }\end{array}$ \\
\hline
\end{tabular}

At the moment, all of the above objects are subject to reconstruction or have already been restored for further normal operation. Below will be presented materials on the existing methods of monitoring structures at power generating enterprises, and an analogue will be proposed.

\section{Existing analogues}

In 2009, the government of the Russian Federation initiated the adoption of the Federal Law No. 384-FZ of 30.12.2009 "Technical regulations on the safety of buildings and 
structures" Chapter 3, Art. 18 "Requirements for ensuring the safety of buildings and structures in case of hazardous natural processes and phenomena and man-made influences" and Chapter 5, Art. 36 "Requirements for ensuring the safety of buildings and structures during operation" [7]. In which one of the key elements of safety assurance is the need to create an automated system for monitoring the stress-strain state of load-bearing structures and power equipment at various special and hydro-generating facilities. Basically, such systems include: string sensors, strain gauges, acoustic emission systems, fiber optic sensors. Separately, it is worth noting dynamic test methods that require the use of expensive vibration diagnostic equipment $[8,9]$.

The features of these systems are shown in Table 2.

Table 2. Advantages and disadvantages of monitoring systems.

\begin{tabular}{|c|c|c|}
\hline Monitoring system & Minuses & Pros \\
\hline 1 & 2 & 3 \\
\hline Strain gauge sensors & $\begin{array}{l}\text { - Relaxation and creep of the } \\
\text { working adhesive layer [10]; } \\
\text { - Influence of temperature on } \\
\text { hysteresis; } \\
\text { - The base peels off from } \\
\text { intense dynamic loads; }\end{array}$ & $\begin{array}{l}\text { - Light weight and size; } \\
\text { - Simplicity of the sensor design } \\
\text { and its attachment to products; } \\
\text { - The ability to measure static } \\
\text { and dynamic deformations [11]. }\end{array}$ \\
\hline String pickups & $\begin{array}{l}\text { - Relaxation of the stress- } \\
\text { strain state of the string } \\
\text { material; } \\
\text { - The impossibility of using } \\
\text { the objects under study in } \\
\text { dynamic test and operation } \\
\text { modes [13]. }\end{array}$ & $\begin{array}{l}\text { - Small inertia; } \\
\text { - High sensitivity [11]. }\end{array}$ \\
\hline Fiber optic sensors & - High price. & $\begin{array}{l}\text { - Resistance to electromagnetic } \\
\text { interference; } \\
\text { - The ability to transmit a signal } \\
\text { over a long distance [11]. }\end{array}$ \\
\hline $\begin{array}{l}\text { Acoustic emission } \\
\text { systems }\end{array}$ & $\begin{array}{l}\text { - The impossibility of using } \\
\text { the objects under study in } \\
\text { dynamic test and operation } \\
\text { modes [10]; } \\
\text { - "Noise" in the received } \\
\text { signal; } \\
\text { - The uniqueness of the } \\
\text { equipment. }\end{array}$ & $\begin{array}{l}\text { - Finding not static, but } \\
\text { developing defects; } \\
\text { - Possibility of only static } \\
\text { observations; } \\
\text { - Versatility in application to } \\
\text { various materials [12]. }\end{array}$ \\
\hline
\end{tabular}

In addition to those listed, the general disadvantages include:

- With long-term operation in harsh conditions, these systems have a high cost;

- Due to the design features of the equipment, there is a "zero drift";

- The reports obtained as a result of monitoring using the above systems do not fully reflect the level of "residual" stresses and accumulated fatigue phenomena in the material of the operating structure. Upon reaching critical values, in practice, this leads to irreversible and avalanche-like destruction. 
Hazardous energy generating objects can come into an emergency state at low loads, since the material contains "residual" stresses that accumulate at the atomic level due to the severe irradiation of the material, if we consider a nuclear power plant. This is confirmed by research by the UCLA team led by Gaurav Sant, who argue that "the minerals calcite and quartz, which often form mineral aggregates in concrete, can be significantly damaged by radiation in the form of neutrons" [15], which in turn leads to a change in the atomic lattice. None of the previously described systems are capable of "catching" these changes.

The calculation methods for determining the stress level in the longitudinal reinforcement of reinforced concrete products recommended in SP 52-101-03 and RD EO 1.1.2.99.0867-2012 using the crack opening width and the distance between cracks, according to the authors, cannot be reliable when using measurement sensors VAT of reinforcement in reinforced concrete structures.

\section{Method}

In order to solve the problems raised, the authors of the article developed an innovative system for monitoring SSS both for ferromagnetic materials used in cladding or in loadbearing metal structures (see Fig. 1) and for assessing SSS of working reinforcement in reinforced concrete structures of hazardous power generating facilities. The structural diagram of the system and an example of its application are described in [13]:

The proposed monitoring system was developed based on the use of the Foerster effect [16], which is based on the dependence of the relative magnetic permeability of ferromagnetic media on the level of stresses acting in the material.

At the same time, the authors received patent No. 2295118 [14] for a magnetoelastic sensor and a system for active monitoring of SSS of ferromagnetic materials and prepared an application for an invention for a method for measuring SSS in working reinforcement of critical reinforced concrete structures of power generating facilities using the same Foerster effect.

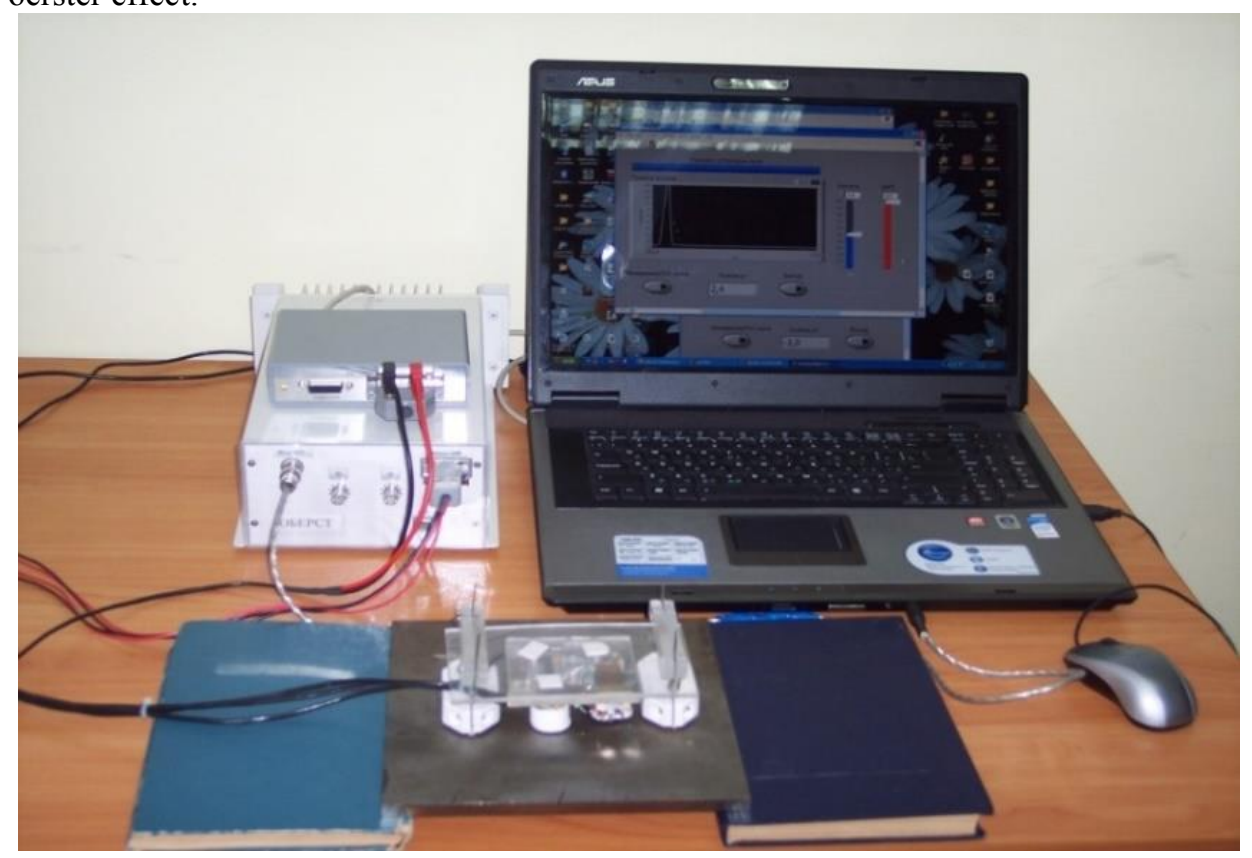

Fig. 1. General view of the monitoring system for ferromagnetic materials [13]. 
The developed sensor has the design shown in Fig. 2.
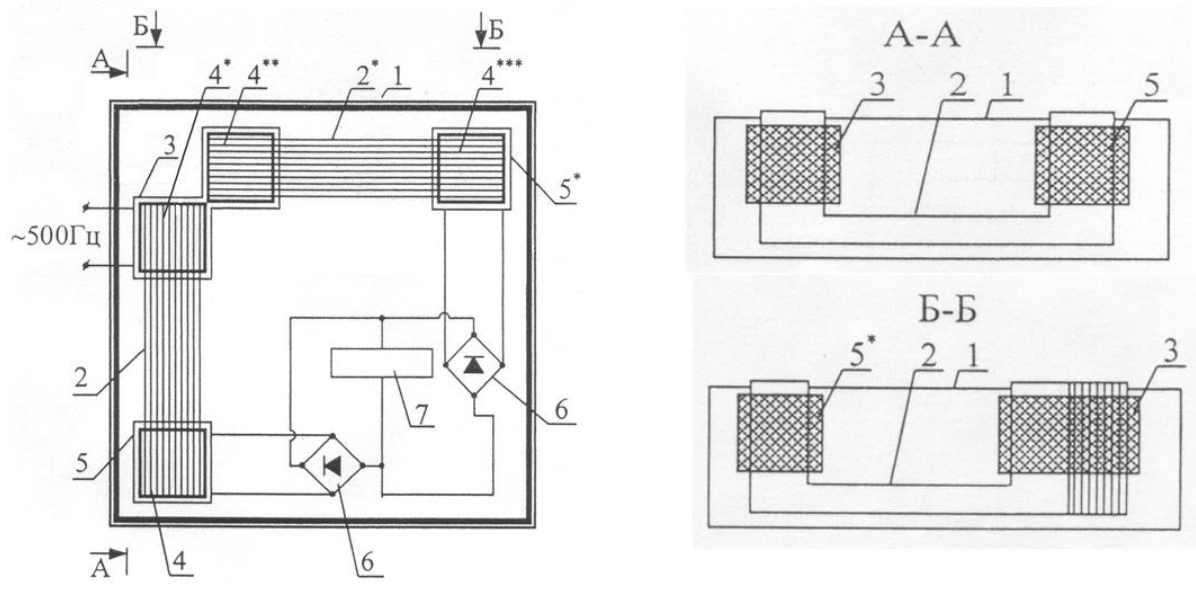

Fig. 2. Design [14].

Case 1., measuring windings 5 and $5 *$, excitation winding 3 , poles of active and passive magnetic circuits $4,4 *, 4 * *, 4 * * *$, Wheatstone bridges 6 , used to convert alternating voltage into direct voltage, which is connected from each from the bridges towards each other to determine the difference of the received signals from each of the measuring windings, due to the use of a special digital measuring system 7 .

Both cores of the working magnetic circuits are placed in the sensor case mutually perpendicular, and the exciting sensor winding is placed on two mutually perpendicularly aligned identical poles of the magnetic cores sensor [14]. To measure the stress-strain state of the metal of power equipment, it is necessary to install a magnetoelastic sensor on the identified "painful" points of the power equipment or supporting building structures, which will make it possible to measure the change in their stress-strain state both in static and dynamic modes. Moreover, not by the fiber deformations of the metal, but by the change in the atomic state of the medium under study.

The developed active monitoring system effectively measures a very wide range of operating parameters of load-bearing structures and power equipment both in static and dynamic modes in accordance with the requirements of STO 70238424.140.035-2009 "Methodology and assessment of the technical state of hydraulic structures during operation" [17], GOST R 22.1.12.-2005 "Safety in emergency situations. A structured system for monitoring and managing engineering systems of buildings and structures" [16].

This monitoring system is able to determine:

- Effective stresses in the material;

- Dynamic stresses in the material;

- Residual stresses, which indirectly characterize the history of object loading during the period of operation;

- Frequency of natural vibrations of power equipment and supporting structures of the investigated object;

- The speed of dynamic vibrations of the structure;

- Acceleration of dynamic vibrations;

- Logarithmic decrement of damping of free vibrations of the object.

But most importantly, this system allows, without the use of expensive inspection, and the use of additional vibration sensors and special equipment - by changing the frequency of natural vibrations of power equipment and the frequency of natural vibrations of loadbearing structures, to determine the level of reduction in the residual resource of power 
equipment and load-bearing structures of power generating structures, which can dramatically increase their level of security.

In addition, the introduction of the proposed monitoring system makes it possible to prevent critical states of the operation of structures during the operation of objects of increased responsibility by creating a rigid electronic feedback between the proposed monitoring system and the existing Federal systems for automatic regulation of the operating mode of power systems in frequency and power (ARCHM) and group regulation of active and reactive power (GRARM) located at the stations themselves.

Comparison of the main technical characteristics of the existing and the proposed monitoring system is presented in table 3 [8].

Table 3. Technical characteristics of existing and proposed monitoring systems [13].

\begin{tabular}{|c|c|c|c|c|c|}
\hline \multirow{2}{*}{$\begin{array}{c}\text { № } \\
\mathrm{p} / \\
\mathrm{p}\end{array}$} & $\begin{array}{c}\text { Name of technical } \\
\text { characteristics }\end{array}$ & $\begin{array}{c}\text { Strain gauge } \\
\text { sensors }\end{array}$ & $\begin{array}{c}\text { String } \\
\text { pickups }\end{array}$ & $\begin{array}{c}\text { Fiber Optic } \\
\text { Sensors }\end{array}$ & $\begin{array}{c}\text { Magnetoelastic } \\
\text { sensors }\end{array}$ \\
\cline { 3 - 6 } 1 & $\begin{array}{c}\text { Measuring range } \\
(\mathrm{MPa})\end{array}$ & \pm 300 & \pm 350 & \pm 400 & \pm 500 \\
\hline 2 & Sensitivity (MPa) & 0.2 & 0.1 & 0.2 & 0.05 \\
\hline 3 & Accuracy (\%) & 5 & 2 & 1 & 0.5 \\
\hline 4 & $\begin{array}{c}\text { Frequency response } \\
(\mathrm{Hz})\end{array}$ & $0-1000$ & - & $0-4000$ & $0-8000$ \\
\hline 5 & $\begin{array}{c}\text { Creep, zero drift } \\
(\%)\end{array}$ & 0,1 & 0,05 & 0,05 & missing \\
\hline 6 & $\begin{array}{c}\text { Operating } \\
\text { temperature range } \\
\left({ }^{\circ} \mathrm{C}\right)\end{array}$ & $-20+40$ & $-30+60$ & $-30+50$ & $-40+70$ \\
\hline 7 & $\begin{array}{c}\text { Possibility of } \\
\text { measuring }\end{array}$ & missing & missing & missing & there is \\
\hline
\end{tabular}

\section{Conclusions}

A comparative analysis of the technical characteristics of classical monitoring systems given in Table 3 and those proposed by the authors using magnetoelastic sensors showed that:

- the existing systems for monitoring the stress level of the material of structures when measuring fiber deformations in practice can reflect not the real state of the material (give a large error). Changes in the temperature or humidity conditions of objects can affect the design or fastening elements of the sensors to the surface of the investigated area.

- in comparison with existing analogues, the proposed magnetometric sensor is capable of reflecting changes in the atomic lattice of a material due to a change in the stress-strain state of the latter;

- due to the possibility of the proposed monitoring system to assess the level of "residual" and acting stresses in the material of construction, it becomes real to increase the degree of reliability of the results obtained in relation to traditional systems;

- the proposed magnetoelastic sensors, due to the absence of adhesive joints in the structure and materials of the body exposed to the environment, make it possible to measure the stress-strain state of the structure throughout the entire service life of critical objects; 
- sensitivity and reliability, in comparison with the traditional known methods for determining the VAT of the material of construction, is higher, at a lower cost;

- complying with the provisions of GOST 31937-2011 Buildings and structures. "Rules for inspection and monitoring of technical condition" the proposed system allows you to measure the level of stress-strain of the material of load-bearing structures, both in static mode and in dynamic modes, while there is no need to use additional electronic equipment;

- It should also be noted that it is possible to measure the dynamic characteristics of an object, in particular: the frequency of natural vibrations of objects, the speed and acceleration of vibrations of individual load-bearing structures of the inspected object, as well as the logarithmic decrement of the fundamental tone of natural vibrations in different directions.

\section{References}

1. Rassokhin G. (2012) On the destruction of the attachment point for the turbine cover of the hydroelectric unit № 2 of the SSHGES from: https://www.plotina.net/sshgesrassokhin-4/

2. RIA Novosti (2008) from: https://ria.ru/20080104/95348159.html

3. Interfax (2018) from: https://www.interfax.ru/russia/612025

4. Atominfo.ru (2013) from: http://www.atominfo.ru/newsd/k0638.htm

5. Vishnevsky B., Zernova L., Morozov A. Novaya Gazeta №79 (2011) from: https://novayagazeta.ru/articles/2011/07/21/44535-bezumnaya-avariya-na-aes-podpiterom

6. Atomic Energy 2.0 energy.ru/news/2016/07/08/67397

(2016) from: https://www.atomic-

7. Technical regulations on the safety of buildings and structures Ф3 №384-Ф3 dated 30.12.2009.

8. Zemlyansky K., Zemlyansky A. An innovative system for active monitoring of the stress-strain state of load-bearing and enclosing structures of power generating facilities // Proceedings of the X Int. scientific. practical conference "Safety in nuclear power" Volgodonsk. BITI (branch) NRNU MEPhI 2014 pp 41-45

9. Zemlyansky K., Zemlyansky A. Innovative system of VAT of supporting structures and power equipment of hydraulic structures. Sat. articles. II International scientific and practical conference BITI (branch) NRNU "MEPhI" 2016 Balakovo. pp 81-90

10. Zemlyansky A., Zemlyansky K. Effective increase of the NPP reliability level due to the introduction of the sixth protective barrier// Proceedings of the VIII Int. scientific. practical. conference "Inspection of buildings and structures: problems and solutions" St. Petersburg, October 13, 2017.

11. Kolosov O. Technical means of automation and control: a textbook for academic bachelor's degree - M.: Yurayt Publishing House, 2017. p 291

12. Acoustic emissions from: https://www.serconsrus.ru/services/akusticheskayaehmissiya/

13. Zemlyanskij A.A., Grigorenko V.P., Zemlyanskij K.A., Dubnov S.A. Effective Increasing of NPP Reliability Introducing the Active Monitoring System of Block Construction Stress-Strain State // Global nuclear safety. 2020. № 1(34). P. 38-47. 
14. Zemlyansky K., Zemlyansky A. Magnetoelastic sensor. Patent № 2295118 C1 BI №1 M., 2007.

15. Arsenal Reinforced Concrete Products (2016) from: http://arsenalgbi.com/home/home/blog1/422-vliyanie-radiatsii-na-beton.html

16. Forster F.Z. fur Metallkunde. \#43. 1952

17. STO 70238424.140.035-2009 "Methodology and assessment of the technical condition of hydraulic structures during operation"

18. Buildings and structures. Rules for inspection and monitoring of technical condition. GOST 31937-2011. Moscow: MITKS 2012. p 68

19. Methodology for assessing the technical condition and residual life of nuclear power plant building structures. RD EO 1.1.2.99.0867-2012 M.: Rosenergoatom Concern OJSC 2012. p 30

20. Monitoring of building structures of nuclear power plants. RD EO 1.1.2.99. 624-2011 M.: Rosenergoatom Concern OJSC 2012. p 68.

21. Zemlyansky A. Monitoring and management of the reliability of buildings and structures for various purposes // Zh. Industrial and civil construction. -M., 2004 № $9 \mathrm{p}$ 39

22. GOST R 22.1.12.-2005 "Safety in emergency situations. Structured system for monitoring and managing engineering systems of buildings and structures "

23. Federal program "Energy strategy of Russia for the period up to 2030" Decree of the Government of the Russian Federation № 1715 of 13.11.2009. 